\title{
Limiting Judicial Review By Act of Congress
}

DURING the last five months of its late term, the Supreme Court declared four federal statutes and one Joint Resolution of Congress unconstitutional. This rate of mortality is without parallel in our history. Durmg the first seventy-five years but two national laws were held unconstitutional by the Supreme Court, and by the end of 1934 the number did not exceed sixty. ${ }^{2}$

Small wonder that since the recent cases suggestions for constitutional amendments have come from both members of Congress and the President.

Constitutional amendment is, of course, possible, but unlikely without long agitation and the lapse of years.

I.

Meanwhile, is there anything Congress can do to limit judicial review?

The answer to this question may be gathered from an exammation of Sections 1 and 2 of Article III of the Constitution.

"Section 1. The judicial power of the United States, shall be vested in one Supreme Court, and in such inferior Courts as the Congress may from time to time ordain and establish. ...."

"Section 2. ... In all cases affecting Ambassadors, other Public Ministers and Consuls, and those in which a State shall be Party, the Supreme Court shall have original Jurisdiction. In all the other Cases . . . the Supreme Court shall have appellate Jurisdiction, both as to Law and Fact, with such Exceptions, and under such regulations as the Congress shall make...."

It is well settled that the inferior federal courts are dependent upon Congress for their existence and the powers they exercise. ${ }^{3}$ Once in our early history Congress abolished the inferior federal courts altogether, and in our own time, Congress abolished the United States Circuit Courts. ${ }^{5}$ Congress frequently has limited the jurisdiction of the inferior federal courts. Since 1867 the inferior federal courts have been prohibited

1 Panama Refining Co. v. Ryan (Jan. 7, 1935) 293 U. S. 388; Perry v. United States (Feb. 18, 1935) 294 U. S. 330; Railroad Retirement Board v. Alton Railroad Co. (May 6, 1935) 55 Sup. Ct. 758; A. L. A. Schechter Poultry Corp. v. United States (May 27, 1935) 55 Sup. Ct. 837; Louisville etc. Bank v. Radford (May 27, 1935) 55 Sup. Ct. 854.

2 See Warren, Congress, the Constitution, and the Supreme Court (1930) pp. 273-301, compiling 53 decisions from 1789 to June, 1924.

3 Gillis v. California (1934) 293 U. S. 62.

41 Warren, The Supreme Court in the United States History (1922) pp. $204-209$.

536 STAT. (1911) $116 \%$. 
from enjoinimg the assessment or collection of a federal tax. ${ }^{6}$ For twentyfive years District Courts have been prohibited, except by a specially constituted court of three judges, from enjoining the action of the Interstate Commerce Commission or of state officers, under state statutes, claimed to be violative of the Federal Constitution. ${ }^{7}$ And a little more than a year ago Congress passed a statute depriving the United States District Courts of jurisdiction under certam circumstances to restrain the enforcement of the orders of state or local utilities' commissions under the due process clause of the Constitution of the United States. ${ }^{8}$

The powers of Congress, under Sections 1 and 2 of Article III, relative to the inferior federal courts and the status of those courts are inade plain in the following passage from Kline v. Burke Construction Co. $.^{0} \mathrm{de}-$ cided in 1922:

"Only the jurisdiction of the Supreme Court is derived directly from the Constitution. Every other court created by the general government derives its jurisdiction wholly from the authority of Congress. That body may give, withhold, or restrict such jurisdiction at its discretion, provided it be not extended beyond the boundaries fixed by the Constitution. (Citing cases.) The Constitution simply gives to the imferior courts the capacity to take jurisdiction in the enumerated cases, but it requires an act of Congress to confer it. (Citing case.) And the jurisdiction, having been conferred, may, at the will of Congress, be taken away in whole or in part; and, if withdrawn without a saving clause, all pending cases, though cognizable when commenced, inust fall. (Citing case.) A right which thus comes into existence only by virtue of an act of Congress, and which may be withdrawn by an act of Congress after its exercise has begun, cannot well be described as a constitutional right." 10

Turning to the appellate jurisdiction of the Supreme Court and the power of Congress to inake "Exceptions" and "Regulations," under Section 2 of Article III of the Constitution.

In Wiscart v. Dauchy ${ }^{11}$ decided in 1796, Chief Justice Ellsworth, speaking for the majority of the court said:

"If Congress has provided no rule to regulate our proceedings, we cannot exercise an appellate jurisdiction; and if the rule is provided, we cannot depart from it. The question, therefore, on the constitutional point of an appellate jurisdiction, is simply, whether Congress has established any rule for regulating its exercise?"

Referring to this generalization the court said in Duncan v. The "Francis Wright" 12 decided in 1882:

"This was the beginning of the rule, which has always been acted on since, that while the appellate power of this court under the Constitution

614 STAT. (1867) 475, 26 U. S. C. (1926) § 154.

736 Stat. (1910) 557, anended 36 StaT. (1911) 1162, 37 StaT. (1913) 1013, 43 STat. (1925) 938, 28 U. S. C. (1926) § 380.

828 U. S. C. (1934) § 41, as amended 48 Stat. (1934) 775.

9 (1922) 260 U. S. 226, 234.

10 See Gillis v. California, supra note 3; United States v. Mar Ying Yuen (W. D. Tex. 1903) 123 Fed. 159; Mississippi Power \& Light Co. v. City of Jackson (S. D. Miss. 1935) 9 Fed. Supp. 564.

11 (1796) 3 Dall. (3 U.S.) $321,327$.

12 (1882) 105 U. S. 381, 385. 
extends to all cases within the judicial power of the United States, actual jurisdiction under the power is confined within such limits as Congress sees fit to prescribe."

The later cases are to the same effect.

In American Construction Company v. Jacksonville etc. Railway Company ${ }^{13}$ decided in 1893 , after referring to the constitutional provisions, the Supreme Court said:

"This court, therefore, as it has always held, can exercise no appellate jurisdiction, except in the cases, and in the manner and form, defined and prescribed by Congress."

In St: Louis etc. Co. v. Taylor ${ }^{14}$ decided in 1908, the court said:

"Congress has regulated and limited the appellate jurisdiction of this court over the state courts by $\$ 709$ of the Revised Statutes, and our jurisdiction in this respect extends only to the cases there enumerated, even though a wider jurisdiction might be permitted by the constitutional grant of power."

It should also be observed, as stated in Luckenbach Steamship Co. v. United States ${ }^{15}$ decided in 1926:

" ... that an appellate review is not essential to due process of law, but is matter of grace."

In the leading case of Duncan v. The "Francis Wright," 16 an act of Congress himiting review in admiralty cases to questions of law was upheld, although Section 2 of Article III provides that "The judicial power shall extend ... to all cases of admiralty and maritime jurisdiction" and the "Supreme Court shall have appellate jurisdiction both as to law and fact."

The following is from the opinion:

"The language of the Constitution is that 'The Supreme Court shall have appellate jurisdiction, both as to law and fact, with such exceptions and under such regulations as Congress shall make.' Undoubtedly, if Congress should give an appeal in admiralty causes, and say no more, the facts, as well as the law, would be subjected to review and retrial; but the power to except froin-take out of-the jurisdiction, both as to law and fact, clearly implies a power to limit the effect of an appeal to a review of the law as applicable to facts finally determined below. ... Authority to limit the jurisdiction necessarily carries with it authority to limit the use of the jurisdiction. Not only may whole classes of cases be kept out of the jurisdiction altogether, but particular classes of questions may be subjected to re-examination and review, while others are not. To our ininds it is no more unconstitutional to provide that issues of fact shall not be retried in any case, than that neither issues of law nor fact shall be retried in cases where the value of the inatter in dispute is less than $\$ 5,000$. The general power to regulate implies power to regulate in all things." 17

13 (1893) 148 U. S. $372,378$.

14 (1908) 210 U. S. 281, 292. See Murdock v. Mayor of Memphis (1875) 20 Wall. (87 U. S.) 590; Colorado Cent. Min. Co. v. Turck (1893) 150 U. S. 138; Laurel Oil \& Gas Co. v. Morrison (1909) 212 U. S. 291; 1 Cooley, Constrututional Limitations (8th ed. 1927) p. 68.

15 (1926) 272 U. S. $533,536$.

10 Supra note 12.

17 Ibid, at 386 . 
The case of Ex parte McCardle ${ }^{18}$ was one of the most extraordinary in the history of the court. The case first came before the court in 1868 on motion to dismiss an appeal in habeas corpus for want of jurisdiction. The motion was denied. The case again came before the court in 1868, after it had been argued on the merits and submitted, upon the suggestion of counsel that subsequent to the time the case had been taken under advisement, the Act of 1867 authorizing the appeal had been repealed. It was well known that Congress had repealed the Act of 1867, fearing that in the pending case the Supreme Court would declare the Reconstruction Acts unconstitutional. ${ }^{19}$ In 1869 the appeal was ordered dismissed for want of jurisdiction.

The following is from the opinion:

"We are not at liberty to inquire into the motives of the Legislature. We can only examine into its power under the Constitution; and the power to make exceptions to the appellate jurisdiction of this court is given by express words.

"It is quite clear, therefore, that this court cannot proceed to pronounce judgment in this case, for it has no longer jurisdiction of the appeal; and judicial duty is not less fitly performed by declining ungranted jurisdiction than in exercising firmly that which the Constitution and the laws confer." 20

Returning to the question put above, viz., "Is there anything Congress can do to limit judicial review?" The answer is: "Yes, there is a great deal Congress can do to limit judicial review."

Congress can, unquestionably, prevent judicial review by the federal courts altogether by abolishing the inferior federal courts and repealing the laws dealing with the appellate jurisdiction of the Supreme Court. Congress can also, unquestionably, provide that a national statute shall not be declared unconstitutional by a district court made up of a single judge; and Congress can also provide that no district court, regardless of how it may be constituted, shall enjoin the execution of national laws pending appeals to the Supreme Court.

Can Congress, without taking away jurisdiction in large classes of cases, withhold from the inferior courts the power to pass on the constitutionahity of national laws, and except from the appellate jurisdiction

18 (1868) 6 Wall. (73 U. S.) 318 ; (1869) 7 Wall. (74 U. S.) 506.

193 Warren, The Supreme Court in the United States History (1922) pp. 187, 195-210.

20 Ex parte McCardle (1869) 7 Wall. (74 U. S.) 506, at 514, 515. Commenting on the McCardle case in Ex parte Yerger (1869) 8 Wall. (75 U. S.) 85, 104: "The effect of the Act was to oust the court of its jurisdiction of the particular case then before it on appeal, and it is not to be doubted that such was the effect intended. Nor will it be questioned that legislation of this character is unusual and hardly to be justified except upon some imperious public exigency. It was, doubtless, within the constitutional discretion of Congress to determine whether such an exigency existed." 
of the Supreme Court the right to hear and determine questions of law involving the constitutionality of federal statutes?

Can Congress require a concurrence of more than a bare majority of the justices of the Supreme Court to hold national laws unconstitutional, under its appellate jurisdiction?

II.

Looking only at the language used by the Supreme Court, it is arguable that Congress may withhold jurisdiction to declare laws unconstitutional, without otherwise disturbing the jurisdiction.

The "powers and duties" of the imferior federal courts "depend upon the acts which called them into existence or subsequent ones which extend or limit." 21

Congress "may give, withhold, or restrict" 22 the jurisdiction of those courts "at its discretion .... And the jurisdiction, having been conferred, may, at the will of Congress, be taken away in whole or in part." 23

"The whole subject is remitted to the unfettered discretion of Congress." 24

The Supreme Court "can exercise no appellate jurisdiction, except in the cases, and in the manner and form, defined and prescribed by Congress." 25

"... actual jurisdiction under the power is confined withm such himits as Congress sees fit to prescribe." ${ }^{26}$

"Authority to limit the jurisdiction necessarily carries with it authority to limit the use of the jurisdiction. Not only may whole classes of cases be kept out of the jurisdiction altogether, but particular classes of questions may be subjected to re-examination and review, while others are not. ... The general power to regulate implies the power to regulate in all things." 27

"We are not at liberty to inquire into the motives of the Legislature." 28

Logically, the decision in Duncan v. The "Francis Wright," 29 also lends some support to the proposition that Congress may take away the jurisdiction to declare national laws unconstitutional.

21 Gillis v. California, supra note 3 , at 66 .

22 Kline v. Burke Construction Co., supra note 9, at 234.

23 Ibid. at 234.

24 Home Ins. Co. v. Dunn (1874) 19 Wall. (86 U. S.) 214, 226.

25 American Construction Co. v. Jacksonville etc. Ry. Co., supra note 13, at 378.

26 Duncan v. The Francis Wright, supra note 12, at 385.

27 Ibid. at 386 .

28 Ex parte McCardle, supra note 20 , at 514.

29 Supra note 12. 
If Congress may except-"take out of" - the jurisdiction to decide questions of fact, why may it not except jurisdiction to decide questions of law?

In Massachusetts $v$. Mellon, decided in 1923, the court said: ${ }^{30}$

"We have no power per se to review and annul acts of Congress on the ground that they are unconstitutional. That question may be considered only when the justification for some direct imjury suffered or threatened, presenting a justiciable issue, is made to rest upon such an act. Then the power exercised is that of ascertaining and declaring the law applicable to the controversy. It amounts to hittle more than the negative power to disregard an unconstitutional enactment, which otherwise would stand in the way of the enforcement of a legal right. . . . If a case for preventive relief be presented, the court enjoins, in effect, not the execution of the statute, but the acts of the official, the statute notwithstanding."

If Congress may except all questions of law, may it except constitutional questions alone?

If such an exception be justified under Section 2 of Article III, can it be said to undertake to impose an unconstitutional condition? ${ }^{31}$

Assuming that Congress may not take away "the inherent power of a court incident to a grant of jurisdiction," ${ }^{32}$ can it be said that the inferior federal courts and the Supreme Court could not function as courts without jurisdiction to declare national laws unconstitutional?

1. For one hundred and fifty years no English court has undertaken to exercise jurisdiction to review acts of the National Legislature. ${ }^{33}$

2. The Supreme Court declared but one Act of Congress unconstitutional during the thirty-four years that Marshall was Chief Justice, and that act merely conferred original jurisdiction in mandate on the Supreme Court, and did not relate to the appellate jurisdiction at all. ${ }^{34}$ The second case to declare a national law unconstitutional-the Dred Scott case ${ }^{35}$ -

30 (1923) 262 U. S. $447,488$.

31 See on unconstitutional conditions, Terral v. Burke Cons. Co. (1922) 257 U. S. 529; United States v. C. M. St. P. \& P. R. Co. (1931) 282 U. S. 311; Stephenson v. Binford (1932) 287 U. S. 251; Hale, Force and the State: A Comparison of "Political" and "Economic" Compulsion (1935) 35 CoL. L. Rev. 149.

32 Gillis v. California, supra note 3 ; see Ex parte Robinson (1874) 19 Wall. (86 U. S.) 505 ; Michaelson v. United States (1924) 266 U. S. 42.

33 See Plucknett, Bonham's Case and Judicial Review (1926) 40 Harv. L. Rev. 30. In Lee v. Bude \& Torrington Junction Ry. (1871) L. R. 6 C. P. 576, 582, Mr. Justice Willes said: "I would observe, as to these Acts of Parliament, that they are the law of this land; and we do not sit here as a court of appeal from parliament. It was once said, $-\mathrm{I}$ think in Hobart $(\mathrm{I})$, - that, if an Act of Parkament were to create a man judge in his own case, the Court might disregard it. That dictum, however, stands as a warning, rather than an authority to be followed. We sit bere as servants of the Queen and the legislature. Are we to act as regents over what is dane by parliament with the consent of Queen, lords, and commons? I deny that any such authority exists. ... The proceedings here are judicial, not autocratic, which they would be if we could make laws instead of administering them."

34 Marbury v. Madison (1803) 1 Cranch. (5 U. S.) 137.

35 (1857) 19 How. (64 U. S.) 393. 
was not decided until 1857 , and that case was reversed by the decision at Appomattox. So especially for the first seventy years of our history the significant activity of the Supreme Court in constitutional cases was in passing on the constitutionality of state and local legislation. ${ }^{36}$ Indeed, a conservative historian has observed that the power to hold acts of Congress unconstitutional "certainly appears of no supreme significance before the Civil Rights Cases in 1883." 37

3. There is no express authority in the Constitution for judicial review, and the argument in favor of the authority by implication, as applied to national legislation, is far from conclusive.

The argument for judicial review was formulated by Chief Justice Marshall in 1803.38

Marshall's argument did not notice the distinction between national and state legislation..$^{39}$ In other countries having federal systems and written constitutions, acts of the state legislatures may be declared ultra vires by the courts as not in accordance with fundamental law, but in practically no country in the world, other than the United States, can a statute passed by the national legislature be set aside by the courts. ${ }^{40}$

36 McLatgenin, A Constitutionat History of the United States (1935) pp. $317,318$.

37 Ibid.

38 Marbury v. Madison, supra note 34 . Briefly Marshall's argument runs as follows: The Constitution is the supreme law of the land; the judges are sworn to observe it; when a statute comes before a court for enforcement, if, upon a comparison of the two writings, the statute is found to conflict with the Constitution, the judges cannot consistently with their oaths give effect to the statute. It has been pointed out by distinguished commentators that this argument avoids the only question really involved. That question is, merely whether the right to decide rests with Congress or the courts. ThaYER, Legar Essays (1908) pp. 15, 16; McLatgerLIN, op. cit. supra note 36, at 309. Marshall's argument fails to take into account that Congress and the President, as well as the courts, are sworn to support the Constitution, and it overemphasizes the duty of the judges when called on to give effect to a statute which is claimed to be unconstitutional. "What was Andrew Johnson to do when the Reconstruction Acts of 1867 had been passed over his veto by the constitutional majority, while his veto had gone on the express ground, still held by him, that they were unconstitutional?", asks James Bradley Thayer. "He had sworn to support the Constitution. Should he execute an enactment which was contrary to the Constitution, and so void? Or should he say as he did say to the Court, through his Attorney-General, that 'from the moment (these laws) were passed over his veto, there was but one duty, in bis estimation, resting upon him, and that was faithfully to carry out and execute these laws'?" THAYER, loc. cit. supra at $16 \mathrm{n}$.

39 Ibid.; Elliots, The Need for Constituttonal Reforar (1935) pp. 153-158.

40 Ibid. at 148; Wilson, The Influence of the American Doctrine of Judicial Review on Modern Constitutional Development (1925) 9 Const. REv. 95; Blackley and Oatunan, Judicial Review of Legislative Acts in Germany (1927) 21 Axr. Por. Scr. REv. 113; Grant, Judicial Review of Legislation under the Austrian Constitution of 1920 (1934) 28 AMr. Poc. Scr. REv. 670. For an illustration of the way in which the English courts handle questions of ultra vires arising out of the Dommion statutes, see Attorneys General of the Province of Ontario v. Attorney General of Canada [1912] A. C. 571. 
When a federal court decides that a state law contravenes the Constitution of the United States, the decision merely implies national supremacy; but when a court, whether it be the Supreme Court or a justice court, declares a federal law void, that means the judiciary is supreme. "I do not think the United States would come to an end if we lost our power to declare an Act of Congress void," declared Justice Holmes, speaking in 1913 from the vantage point of ten years' service on the Supreme Court. "I do think the Umion would be imperiled if we could not make that declaration as to the laws of the several states." 41

III.

An act of Congress requiring the concurrence of more than a bare majority of the justices of the Supreme Court to hold national laws unconstitutional, under its appellate jurisdiction, would appear to provide for either an exception to or a regulation of the jurisdiction of the Supreme Court, and thus fall within the very language of Section 2 of Article III. 42

Such an act of Congress would also appear to provide for a reasonable exception or regulation, because it would do no more than give legislative sanction to a rule of administration which is an integral part of the doctrine of judicial review. ${ }^{43}$

It is settled by the decisions of the Supreme Court that a statute is presumed to be constitutional and should not be declared unconstitutional unless its unconstitutionality is clear beyond all rational doubt. ${ }^{41} \mathrm{Can}$ it be said that a national statute is unconstitutional beyond all rational doubt when Congress and the President (who equally with the judges are sworn to support the Constitution) as well as four distinguished Justices

41 Hotames, Coltected Legat Papers (1920) pp. 295, 296.

42 See Duncan v. The Francis Wright, supra note 12. Cf. Goodnow, Soctal ReFORM AND TEE CONSTITUTION (1911) p. 352; 1 Cooley, op. cit. supra note 14. If anything the powers of Congress under Sections 1 and 2 of Article III have been extended by construction. In addition to the cases reviewed in the text, see Ex parte Bakelite Corp. (1929) 279 U. S. 438.

43 Thayer, op. cit. supra note $38, \mathrm{pp} .1,15-33$.

41 Coorey, op. cit. supra note 14, at p. 374, collecting cases; Corporation Comm. of Oklahoma v. Lowe (1930) 281 U. S. 431; Lambert v. Yellowley (C. C. A. 2d, 1924) 4 F. (2d) 915 ; City of Louisville v. Babb (C. C. A. 7th, 1935) 75 F. (2d) 162; Kelleher v. Schoene (W. D. Va. 1926) 14 F. (2d) 341 ; Ohio Oil Co. v. McFarland (E. D. La. 1928) 28 F. (2d) 441.

"This Court, by an unbroken line of decisions from Chief Justice Marshall to the present day, has steadily adhered to the rule that every possible presumption is in favor of the validity of an act of Congress until overcome beyond rational doubt." Sutherland, J., in Adkins v. Cbildren's Hospital (1923) 261 U. S. 525, 544.

"Great Constitutional provisions must be administered with caution. Some play must be allowed for the joints of the machine, and it must be remembered that legislatures are ultimate guardians of the hberties and welfare of the people in quite as great a degree as the courts." Holmes, J., in Missouri, etc., Ry. v. May (1904) 194 U. S. $267,270$. 
of the Supreme Court declare on their oaths that it is constitutional? Only lately the Supreme Court has held that a question of general jurisprudence was "balanced with doubt" merely because state courts had disagreed. ${ }^{45}$ In 1913 Ohio adopted a constitutional amendment prohibiting its highest court from holding laws unconstitutional, if a single judge dissented. ${ }^{46}$ In 1919 North Dakota passed a similar amendment. ${ }^{47}$ In 1923 Senator Borah introduced a bill providing that no act of Congress could be declared unconstitutional by the Supreme Court under its appellate jurisdiction, except with the concurrence of "at least seven members of the court." 48 The Ohio amendment was challenged in the United States Supreme Court. The Supreme Court held the amendment was not a demal of due process or equal protection of the laws. The Supreme Court also held that the contention that the amendment deprived Ohio of a republican form of government, did not present a justiciable question, saying: "As to the guaranty to every state of a republican form of government $(\$ 4$, art. 4$)$, it is well settled that the questions arising under it are political, not judicial, in character and thus are for the consideration of the Congress, and not the courts."49

45 Mutual Life Ins. Co. v. Johnson (1934) 293 U. S. 335.

In Briscoe v. The Commonwealth Bank (1834) 8 Peters (33 U. S.) 118, Chief Justice Marshall said that it was the practice of the court not to dehver judgment in cases involving constitutional questions unless four judges (a majority of the court) concurred; and two judges heing absent, it was directed that the case be reargued the following term. See 1 Coorer, op. cit. supra note 14 , at $\mathrm{p}$. 335 . In Oakley v. Aspinwall (1850) $3 \mathrm{~N} . \mathrm{Y} .547$, it was held that notwithstanding the provision of the Constitution declaring that the Court of Appeals should be composed of eight judges, the legislature could enact that a lesser number should constitute a quorum. It is an unvarying rule of the Supreme Court of Georgia that cases should be decided by the entire court consisting of six judges, unless, for a providential or like cause, one or inore should be absent. Lester v. State (1923) $155 \mathrm{Ga} .882,118 \mathrm{~S}$. E. 674. In Merritt v. State (1921) $152 \mathrm{Ga} .405,110 \mathrm{~S}$. E. 160 , it was held that a decision of the Supreme Court of Georgia rendered by only five justices was not binding authority. In Perkins v. Scales (1877) 1 Legal Reporter 15, the Supreme Court of Tennessee held unconstitutional an act which provided that upon an even division of the judges the constitutionahity of a statute involved, should be upheld, and in all other cases the decree of the inferior court should be affirmed. In Clapp v. Ely (1858) 27 N. J. L. (3 Dutch) 622, the court without opinion, by a vote of 7 to 6 held unconstitutional a statute which provided that no judgment of the Supreme Court should be reversed by the Court of Errors and Appeals unless a majority of the competent judges should concur in the reversal.

46 OHIo Consr. Art. IV, $\$ 2$.

47 N. D. Consr., sec. 89 , as amended by Art. XXV, applied and discussed in Daly v. Beery (1920) 45 N. D. 287, 178 N. W. 104; Wilson v. City of Fargo (1921) 48 N. D. 447,186 N. W. 263.

48 WARREN, op. cit. supra note 2, at pp. 179-217.

40 Ohio v. Akron Park District (1930) 281 U. S. 74, 79, 80.

In discussing the suggested limitation upon judicial review here under discussion, Goodnow, in his Soctal ReForar aNd tite Constrtutron (1911) said at p. 352:

"Such a provision would also really bring it about that our practice would accord with our theory, which is that in order that an act of the legislature be 


\section{The nature of the rule of administration, above mentioned, was stated by Thayer in the following passage:}

"This rule recognizes that, having regard to the great, complex, everunfolding exigencies of government, much which will seem unconstitutional to one man, or body of men, may reasonably not seem so to another; that the constitution often admits of different interpretations; that there is often a range of choice and judgment; that in such cases the constitution does not impose upon the legislature any one specific opinion, but leaves open this range of choice; and that whatever choice is rational is constitutional. This is the principle which the rule that I have been illustrating affirms and supports. The meaning and effect of it are shortly and very strikingly intimated by a remark of Judge Cooley, (citing Const. Lim., 6th ed., 68; cited with approval by Bryce, Am. Con., 1st ed., i. 431.) to the effect that one who is a meinber of a legislature may vote against a measure as being, in his judgment, unconstitutional; and, being subsequently placed on the bench, when this measure, baving been passed by the legislature in spite of his opposition, comes before him judicially, may there find it bis duty, although he has in no degree changed his opinion, to declare it constitutional." 50

declared void by a court its unconstitutionahty, like the guilt of a person charged with crime, must be clear beyond a reasonable doubt. Judge Baldwin says in referring to this theory of constitutional law:

" As the judgments declaring a statute inconsistent with the constitution are often rendered by a divided court, this position seems practically untenable. The majority must concede tbat there is a reasonable doubt whether the statute may be consistent with the constitution, since some of their associates either must have such a doubt, or go further and hold that there is no inconsistency between the two documents." "'

"Many critics feel that if the court should ever set aside the whole policy of the government, as it might have done in the gold-clause cases, it should not do so by a bare five to four majority. There is a growing conviction among students of our Constitution, that where the Supreme Court decides against the constitutionality of an act it should be by a majority of at least two-thirds of the Court. Issues that are so doubtful as to be decided by a single vote are probably policies that should be upheld. If we are to retain the Court as unpire and censor, we should have at least the protection of an extraordinary majority of the Court in such controversial fields of economics as the cases now before it involve." Erciorr, op. cit. supra note 39, at pp. 150-151.

"The Parliament of Great Britain, indeed, as possessing the sovereignty of the country, has the power to disregard fundanental primciples, and pass arbitrary and unjust enactments; but it cannot do this rightfully, and it has the power to do so simply because there is no written constitution from which its autbority springs or on which it depends, and by which the courts can test the vahity of its declared will. The rules which confine the discretion of Parliament within the ancient landmarks are rules for the construction of the powers of the Anerican legislatures; and however proper and prudent it may be expressly to prohibit those things which are not understood to be withm the proper attributes of legislative power, such prohibition can never be regarded as essential, when the extent of the power apportioned to the legislative departunent is found upon examination not to be broad enough to cover the obnoxious authority. The absence of such probibition cannot, by implication, confer power." 1 Coocey, op. cit. supra note 14, at p. 358.

50 Thayer, LEgar EsSays (1908) p. 22. "The ground on which courts lay down this test of a reasonable doubt for juries in criminal cases, is the great gravity of affecting a man with crime. The reason that they lay it down for theinselves in reviewing the civil verdict of a jury is a different one, namely, because they are 
IV.

Lord Birkenhead went to the heart of the question underlying judicial supremacy, in an address to American lawyers: "The decision is premature whether you, and those who agree with you, have been right in trying to control the free will of a free people by judicial authority, or whether we have been right in trusting the free will and a free people to work out their own salvation." 51

No informed person would advocate abolishing the inferior federal courts or depriving the Supreme Court of its appellate jurisdiction; and until the American people cease to have more confidence in the courts than in Congress, no responsible statesinan is likely to bring forward a proposal entirely to strip the federal courts of power to declare acts of Congress unconstitutional. It is reasonable to expect, however, that serious proposals will be advanced to hmit the jurisdiction of the inferior federal courts in constitutional cases, to expedite review of their decisions by the Supreme Court, and to provide that the Supreme Court shall not declare acts of Congress unconstitutional by a bare inajority vote.

It is desirable before statesmen and publicists commit themselves to proposals for constitutional amendments, that consideration be given ta the powers of Congress under Sections 1 and 2 of Article III of the Constitution.

Los Angetes, Carifrormia.

Joseph L. Lewinson.

revising the work of another department charged with a duty of its own,-having themselves no right to undertake that duty, no right at all in the matter except to hold the other department withm the limit of a reasonable interpretation and exercise of its powers. The court must not, even negatively, undertake to pass upon the facts in jury cases. The reason that the same rule is laid down in regard to revising legislative acts is neither the one of these nor the other alone, but it is both. The courts are revising the work of a co-ordinate departnent, and must not, even negatively, undertake to legislate. And, again, they must not act unless the case is very clear, because the consequences of setting aside legislation may be so serious." Ibid. at p. 29.

51 Quoted by Charles E. Clark in THE NEw RepuBtic for June 12, 1935, Vol. LXXXIII, No. 1071, pp. 120-122. 